Mini Review

\title{
Seaweeds from Halimeda genus as sources of natural antioxidants
}

\begin{abstract}
Seaweeds have recently attracted much attention as a source of antioxidant compounds due to, at least in part, to epidemiological research that strikethrough has supported the existence of an inverse correlation between the incidence of different diseases and consumption of seaweeds. ${ }^{1-4}$ Additionally, different compounds such as carotenoids, mycosporine-related amino acids and terpenoids together with phenolic compounds have been identified among the main entities responsible for these properties in marine algae. ${ }^{5,6}$

Halimeda genus has been investigated over the past years by our group as a source of natural antioxidants, neuro- and hepato-protectant compounds. Indeed, several lines of results have documented the ability of this natural product to target free-radical- mediated processes on in vitro and in vivo experimental models. ${ }^{9-15}$ Thus, current results support the notion that marine seaweeds Halimeda spp are a source of hydrophilic antioxidants, which could be further recommended for the prevention of oxidative stress-related disturbances, and can be of usefulness either as dietetic supplements or as food ingredients.
\end{abstract}

Keywords: seaweeds, antioxidants, halimeda, natural products, phytodrugs
Volume 5 Issue $6-2017$

\author{
Ana Mara de Oliveira Silva,Alexis Vidal \\ Novoa, Daylin Diaz Gutierrez, Jorge Mancini \\ Filho \\ Faculty of Biology, University of La Habana, Calle 25 \# 455 e/ J e \\ I,Vedado, CP I4 000, La Habana, Cuba
}

Correspondence: Alexis Vidal Novoa, Faculty of Biology, University of La Habana, Calle 25 \# 455 e/ J e I,Vedado, CP I4 000, La Habana, Cuba, Email alexis.vidal@infomed.sld.cu

Received: July 16, 2017 | Published: August 21, 2017

\section{Discussion}

Oxidative stress and its clinical implications may be considered relatively innovative research. From the 1970s there has appeared an intensified work on this topic, which is interesting because as early as in 1956 Hardman suggested the toxicity of free radicals and their possible consequences in the genesis of different diseases, this hypothesis was confirmed in 1962 by Gerschamn. This process is closely linked with a variety of pathologies which include AIDS, atherosclerosis, diabetes, neurodegenerative diseases, chemical carcinogenesis, intoxication with certain xenobiotics and even natural aging and apoptosis processes. ${ }^{16,17}$

Oxidative stress is currently defined as the imbalance that occurs between prooxidants reactions (producers of free radical) and antioxidant mechanisms (processes to inactivate the free radical), generally caused by increased production of free radical, so it has been postulated that one way to stop this process is through the supply of antioxidant substances. ${ }^{18}$

The protection of mammals against oxidative stress occurs in different ways. ${ }^{19}$

a. Indirect antioxidants that are intended to prevent the formation of new free radicals, enzymes and cytosolic proteins that catalyze the removal of ROS.

b. Different authors have remarked that the presence of phenolic compounds in seaweeds confers them with a heavy metal chelating capacity, which is also related to $\mathrm{OH}$. radical scavenging. ${ }^{20}$ Diaz \& Vidal et al..$^{15,21}$ demonstrated that the antioxidant properties of Halimeda spp could be explained by the Fe3+ chelating capacity of polyphenolic compounds such as phenolic acids. Halimeda spp have a high content of polyphenolic compounds..$^{10,11}$

c. Direct antioxidants that have the function of eliminating formed free radicals before they can start a specific damage, and this is done with endogenous antioxidant biomolecules located in the cell membrane and in the cytosol or exogenous compounds provided by the diet.Halimeda spp extracts exhibited a high free radical scavenging activity which could be explained by its polyphenolic compounds content. ${ }^{7-15,21}$

d. Others compounds modulate positively the cellular capacity for confronting the generation of levels high ROS and RNS and repair cellular structures damaged by the attack of the free radical. Different molecules, including enzymes, modulate positively the cellular capacity of repairing cellular structures damaged by the attack of the free radical. Catalase, superoxide-dismutase and glutathione-peroxidase enzymes are considered to be fundamental antioxidant defense system in mammals, and it was demonstrated that oxidative stress significantly reduced the activities of these enzymes. We observed that the treatment with the seaweed Halimeda spp led to a significant increase in the activity of these enzymes, which in turn resulted in an enhanced antioxidant defense. Mancini-Filho et al. ${ }^{12}$ reported an over-expression of catalase genes by treatment with FPA from Halimeda monile, while de Oliveira e Silva et al. ${ }^{14}$ by RT/PCR analysis showed an increase in the catalase gene expression in the group treated with free phenolic acid (FPA) fractions from Halimeda opuntia, suggesting the inductor effect of these compounds on the enzyme genes. Accordingly, Vidal et al. ${ }^{21}$ demonstrated similar effect with Halimeda incrassata.

Actually it has been demonstrated that seaweeds contribute significantly to this purpose. Since ancient times, seaweed has been used as a diet component in several parts of the world, mainly in Asian countries. Additionally seaweeds exhibit different phyototherapeutic properties, including antioxidant activity and, consequently, during the last years, the interest on the study of seaweeds as sources of bioactive compounds has increased..$^{22-23}$ A correlation has also been found between the consumption of phenolic compounds in general, and seaweeds in particular, and the incidence of cardiovascular diseases. ${ }^{2}$ Epidemiological research has been also suggested their positive effects on human health with an inverse correlation between the incidence of different diseases, related to oxidative stress and the 
consumption of seaweeds. ${ }^{24}$ Others studies have also demonstrated the different therapeutic properties of these marine algae, which were verified in vitro as well as in vivo. $3,4,25,26$

It is very interesting to note that although algae have traditionally formed part of the diet of different countries, they have been less used as phytopharmaceutical or traditional medicine..$^{27-28}$ The interest on the study of seaweeds as sources of antioxidants compounds has increased in the last years. Seaweed extracts have the ability to inhibit lipid peroxidation or to scavenge free radicals. ${ }^{29}$ In vivo studies have confirmed the antioxidant abilities of seaweed extracts, as well, $3,5,6,30$ which has suggested their possible uses as phytopharmaceutical and/ or nutraceuticals.

These properties could be explained on the basis of their chemical components. Among the main entities responsible for these properties in marine algae, different compounds have been identified such as mycosporine-related aminoacids, carotenoids, and terpenoids. However, several authors consider polyphenols as such phenolic acids, phlorotannins, and bromophenols the most relevant compounds to explain the antioxidant properties of seaweeds. ${ }^{5,6}$ In our previous work, Vidal et al. ${ }^{10}$ identified 8 phenolic acids in Halimeda opuntia and H. monile (Chlrophyta) respectively. They reported that salicylic, cinnamic, gallic, pirogalic and cafeic acids were the principal polyphenolic compounds in both seaweeds. In Halimeda incrassata, it was identified that there were major polyphenolic compounds of salicylic and ferulic acids, and they suggested that their levels were related to the antioxidant activity of the seaweed ${ }^{11}$ while in Halimeda monile the main components were salicylic, cinnamic, gallic, and caffeic acids. Yoshie et al. identificated caffeic acid and flavonoids in Halimeda macroloba. ${ }^{31}$

In general, Halimeda genus are green seaweeds that grows in shallow waters of tropical regions. They are harmless, very easy to collect, and a potential source of phytomedicines. These organisms are largely exposed to a combination of sunlight and oxygen that leads to the formation of free radicals. However, the absence of oxidative damage on the structural components of seaweeds and their stability to oxidation during storage indicate that their cells should have potent protective antioxidative defense systems. ${ }^{32}$

Table I Antioxidant activity and total phenolic compounds content in Halimeda spp

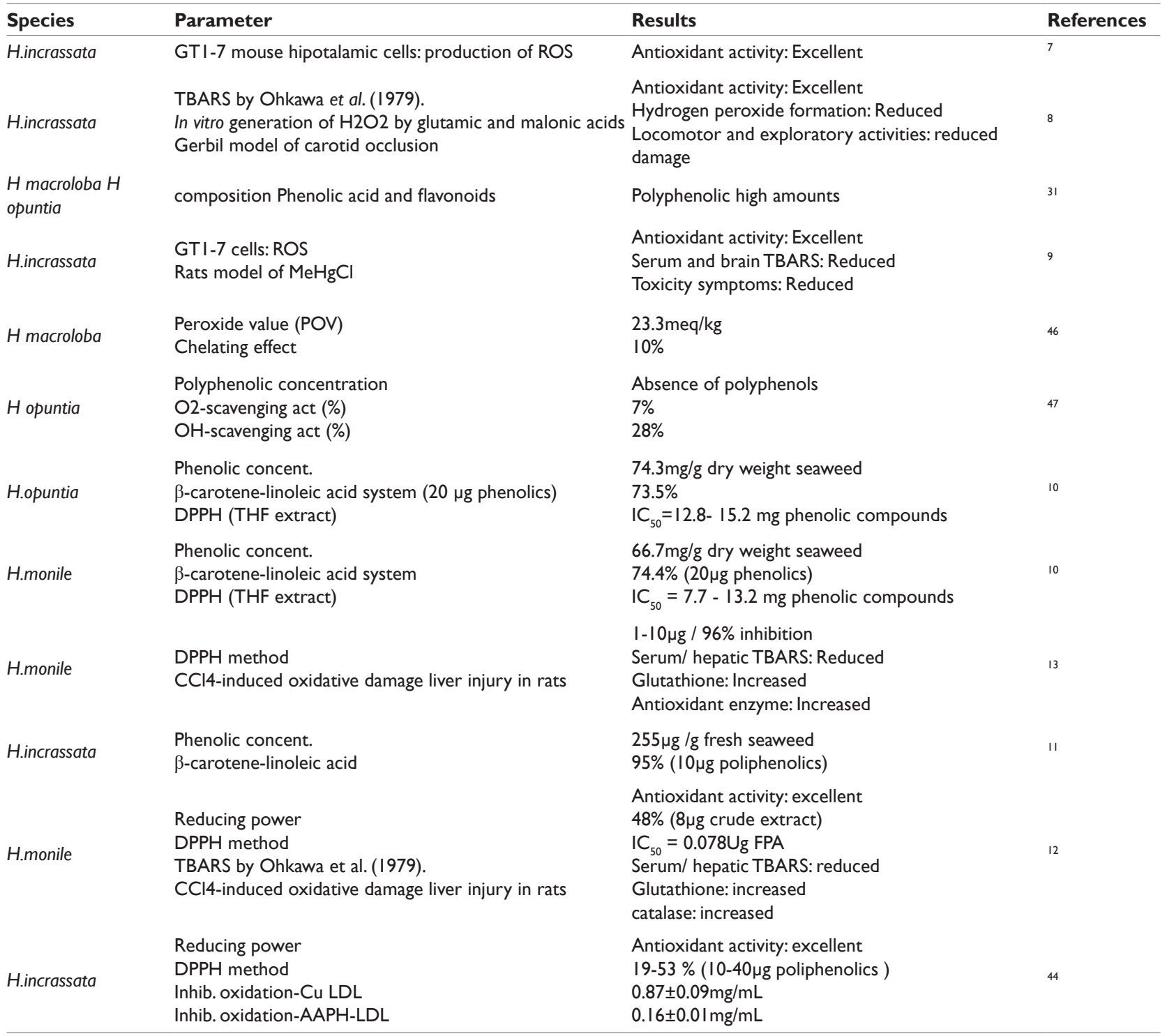


Table Continued..

\begin{tabular}{|c|c|c|c|}
\hline Species & Parameter & Results & References \\
\hline H.opuntia & $\begin{array}{l}\text { Reducing power } \\
\text { DPPH method } \\
\text { CCl4-induced oxidative damage liver injury in rats }\end{array}$ & $\begin{array}{l}\text { Antioxidant activity: excellent } \\
48 \% \text { inhibition }(7 \mathrm{mg} / \mathrm{mL}) \\
\text { Serum and hepatic TBARS: reduced } \\
\text { Antioxidant enzymes: increased }\end{array}$ & 14 \\
\hline H.incrassata & $\begin{array}{l}\text { DPPH method } \\
\text { ORAC } \\
\text { Inhib. LDL oxidation } \\
\text { Effect on smooth muscle cell migration }\end{array}$ & $\begin{array}{l}\mathrm{IC}_{50}=0.27 \mathrm{mg} / \mathrm{mL} \\
3960 \text { trolox equivalents } / \mathrm{g} \text { dry seaweed } \\
0.8 \mathrm{mg} / \mathrm{mL} \\
43 \% \text { inhibition of migration/ transwell assay } \\
\text { decrease migrated area in the wound scratch model }\end{array}$ & 45 \\
\hline H.opuntia & $\begin{array}{l}\text { Reducing power } \\
\text { DPPH method } \\
\text { TBARS by Ohkawa et al. (1979) } \\
\text { Inhibition of haemolysis }\end{array}$ & $\begin{array}{l}\text { Antioxidant activity: excellent } \\
\mathrm{CI} 50=12,34 \pm 0,30 \mathrm{mg} / \mathrm{mL} \\
\mathrm{CI} 50=1,25 \pm 0,31 \mathrm{mg} / \mathrm{mL} \\
82 \%(10 \mathrm{mg} / \mathrm{mL} \text { phenolics }))\end{array}$ & 15 \\
\hline H.incrassata & $\begin{array}{l}\text { desoxirribose oxidation EDTA } \\
\text { desoxirribose oxidation } \\
\text { DPPH method } \\
\text { CCl4-induced oxidative damage liver injury in rats }\end{array}$ & $\begin{array}{l}I C_{50}=1.9 I \pm 0.09 \mathrm{mg} / \mathrm{mL} \\
I C_{50}=2.95 \pm 0.01 \mathrm{mg} / \mathrm{mL} \\
I_{50}=0.4627 .1 \mu \mathrm{g} \text { polyphenolic } \\
\text { Hepatic TBARS: Reduced } \\
\text { Glutathione: Increased } \\
\text { Antioxidant enzymes: Not altered }\end{array}$ & 21 \\
\hline
\end{tabular}

Some species from the genus Halimeda have been demonstrated to be phytopharmaceuticals. Over the last few years, the genus Halimeda has been studied for different pharmacological properties as antimicrobial activity, induction of apoptosis, anti-trichomonal, and antiinflammatory activity. ${ }^{33-40}$ The antitumour effect was detected by induction of apoptosis in leukemia cells, using extracts from $H$. discoidea. ${ }^{41}$ Moreover, the genus Halimeda has been studied for antioxidant properties; animal studies carried out in our laboratory have shown that Halimeda spp effectively attenuates oxidative stress exhibiting neuroprotective and hepatoprotective activities. ${ }^{8,9,12-14,21,37,39,42}$ In the quest for more potent antioxidants from natural sources, our group has been especially interested in studying the beneficial properties of seaweed from the Halimeda genus for an application in biomedicine in hepato-, neuro- and athero-protection.

It has been shown that Halimeda spp has a high phenolic content $^{10-13}$ together with low amounts of other antioxidants, such as ascorbate, $\beta$-carotene, chlorophylls, and selenium; taken together the ensemble of these compounds can explain its antioxidant properties. In our laboratory, we have identified and quantitated phenolic acids as major component of Halimeda spp such as salicylic, cinamic, galic pyrogalic, ferulic and caffeic acids and it has been suggested that the significant antioxidant activity displayed by Halimeda extract is at least partly related to its high levels of total phenolic compounds and particularly due to the phenolic acids content. ${ }^{10-12}$

Halimeda spp has been investigated over the past years by our group as a source of natural antioxidants and hepato- neuro-protectant compounds. A summary of this research is shown in Table I. In several works it has been demonstrated the ability of Halimeda to capture free radicals and inhibit lipoperoxidation. These biological activities were confirmed in different models with excellent results. Indeed, several lines of results have documented the ability of aqueous extract from these seaweeds to target free-radical mediated processes in vitro cell culture models such as GT1-7 mice hypothalamic immortalized and Vero cells. ${ }^{7-15,21}$

Significant antioxidant activity of Halimeda extracts has been also observed in animal models, indicating great potential for phytotherapeutic, nutraceutical, or both applications. Animal studies (CCl4-induced oxidative damage in rat liver, Gerbil model of global isquemia and rats intoxicated with Methyl- mercury) carried out in our laboratory have shown that Halimeda genus effectively attenuates oxidative damage and consequently it produces neuro- and hepatoprotection.

In previous in vitrostudies, Halimeda spp seaweeds have been described as having a relationship between antioxidant activity and antiatherogenic properties. Zaldivar et al. ${ }^{43}$ have indicated an antiatherogenic effect of the Halimeda incrassata in atherosclerosis progression in apo E-/- mice and Costa-Mugica et al., ${ }^{44,45}$ adds evidence to a potential atheroprotective application of $\mathrm{H}$. incrassata considering its antioxidant action and its high activity for targeting LDL oxidation and smooth muscle cell migration.

\section{Conclusion}

In summary, the green (no explained in above) seaweeds Halimeda spp displays a potent antioxidant activity, which could be at least partially explained by the presence of several phenolic acids, although the involvement of other phenolic compounds is not excluded. Thus, current results support the notion that marine's algae Halimeda is a potential source of hydrophilic antioxidants, which could be further recommended for the prevention of oxidative stress-related disturbances, and can be of usefulness either as dietetic supplements, drugs or as food ingredients.

\section{Acknowledgments}

None.

\section{Conflicts of Interset}

None.

\section{References}

1. Mac Artain P, Gill CIR, Brooks M, et al. Nutritional value of edible seaweeds. Nutr Rev. 2007;65(12):535-543.

2. Bocanegra A, Bastida S, Benedí J, et al. Characteristics and Nutritional and Cardiovascular-Health Properties of Seaweeds. J Med Food. 2009;12(2):236-258

3. O’Sullivan L, Murphy B, McLoughlin P, et al. Prebiotics from Marine Macroalgae for Human and Animal Health Applications. Mar Drugs. 2010;8(7):2038-2064 
4. Gomez-Gutierrez CM, Guerra-Rivas G, Soria-Mercado IE, et al. Marine edible algae as disease preventers. Adv Food Nutr Res. 2011;64:29-39.

5. Dutra-Rocha F, Crespo-Pereira R, Coelho-Kaplan MA, et al. Produtos naturais de algas marinhas e seu potencial antioxidante. $\mathrm{Br} J$ Pharmacogn. 2007; 17(4):631-639.

6. Batista González MB, Charles J, Mancini-Filho J, et al. Las algas marinas como fuentes de fitofármacos antioxidantes. Rev Cub Plantas Med. 2009;14(2):1-18.

7. Fallarero A, Loikkanen JJ, Männistö PT, et al. Effects of aqueous extracts of Halimeda incrassata (Ellis) Lamouroux and Bryothamnion triquetrum (S.G.Gmelim) Howe on hydrogen peroxide and methyl mercury-induced oxidative stress in GT1-7 mouse hypothalamic immortalized cells. Phytomedicine. 2003;10(1):39-47.

8. Rivera F, Fallararo A, Castañeda $\mathrm{O}$, et al. Antioxidant activity in vivo and in vitro of Halimeda incrassata aqueous extracts. Food Science Technology. 2003;23(2):256-263.

9. Fallarero A, Loikkanen JJ, Mancini-Filho J, et al. Antioxidant and neuroprotective activity of the extract from seaweed Halimeda incrassata (Ellis) Lamouroux, against in vitro and in vivo toxicity induced by methylmercury. Vet Hum Toxicol. 2004;46(1):1-5.

10. Vidal A, Silva de Andrade-Wartha ER, de Oliveira e Silva AM, et al Actividad antioxidante y polifenoles de algas marinas verdes Halimeda opuntiay Halimeda monile. Ars Pharm. 2009;50(1):24-31.

11. Vidal A, Silva de Andrade-Wartha ER, Fallarero A, et al. Antioxidant activity and bioactive components from the seaweed Halimeda incrassata (Ellis) Lamouroux. Braz J Pharmacogn. 2011;21(1):53-57.

12. Mancini J, Vidal A, Batista AE, et al. Free phenolic acids form the seaweed Halimeda monile with antioxidant effect protecting against liver injury. Naturforsch. 2009;64(9-10):657-663.

13. Batista Gonzalez AE, de Oliveira e Silva AM, Vidal Novoa A, et al Analysiss of antioxidant properties of hydrophilic fractions from seaweed Halimeda monile L. and its function in vivo. J Food Biochem. 2012;36(2):189-197.

14. de Oliveira e Silva AM, Vidal Novoa A, Batista-González AE, et al Antioxidant activity and hepatoprotectivie properties of polyphenols in vitro and in vivo from seaweeds Halimeda opuntia (Linnaeus) Lamouroux. Redox Rep. 2012;17(2):47-53.

15. Díaz Gutiérrez D, Méndez Ortega W, de Oliveira e Silva AM, et al. Comparación de las propiedades antioxidantes y contenido de polifenoles de extractos acuosos de las algas marinas Bryothamnion triquetrum y Halimeda opuntia. Ars Pharm. 2015;56(2):89-99.

16. Aruoma OI. Free radical, oxidative stress, and antioxidants in human health and disease. Journal of the American Oil Chemists' Society. 1998;75(2):199-212.

17. Lipton P. Ischemic cell death in brain neurons. Physiol Rev. 1999;79(4):1431-1568.

18. Pisoschi AM, Pop A. The role of antioxidants in the chemistry of oxidative stress: A review. Eur J Med Chem. 2015;97:55-74.

19. Aruoma OI. Characterization of drugs as antioxidant prophylactics. Free Rad Biol Med. 1996;20(5):675-705.

20. Yuan YV, Walsh NA. Antioxidant and antiproliferative activities of extracts from a variety of edible seaweeds. Food Chem Toxicol. 2006;44(7):1144-1150.

21. Vidal Vidal-Novoa A, Costa-Mugica A, Zulueta-Díaz Y, et al. Antiatherogenic Properties Associated with the Antioxidant Activity from the Hydrophilic Extracts of Halimeda Incrassata Seaweed. Afr $J$ Agric Res. 2017;12(4):208-220.

22. Proksch P, Edrada-Ebel RA, Ebel R. Drugs from the sea- Opportunities and obstacles. Mar Drugs. 2003;1(1):5-17.
23. Lordan S, Ross RP, Stanton C. Marine bioactives as functional food ingredients: Potential to reduce the incidence of chronic diseases. Mar Drugs. 2011;9(6):1056-1100.

24. Karakaya S. Bioavailability of phenolic compounds. Crit Rev Food Sci Nutr. 2004;44(6):453- 464.

25. Kang K, Park Y, Hwang HJ, et al. Antioxidative properties of brow $n$ algae polyphenolics and their perspectives as chemopreventive agents against vascular risk factors. Arch Pharm Res. 2003;26(4):286-293.

26. Shin HC, Hwang HJ, Kang K J, et al. An antioxidative and antiinflammatory agent for potential treatment of osteoarthritis from Ecklonia cava. Arch Pharm Res. 2006;29(2):165-171.

27. Cornish ML, Garbary DJ. Antioxidant from macroalgae: potential application in human health and nutrition. Algae. 2010;25(4):155-171.

28. Núñez R, Garateix A, Laguna A, et al. Caribbean marine biodiversity as a source of new compounds of biomedical interest and others industrial Applications. Pharmacologyonline. 2006;3:111-119.

29. Athiperumalsami T, Rajeswari VD, Poorna SH, et al. Antioxidant activity of seagrasses and seaweeds. Botanica Marina. 2010;53(3):251-257.

30. Nakai M, Kageyama N, Nakahara K, et al. Phlorotannins as radical scavenger's from the extract of Sargassum ringgoldianum. Mar Biotechnol. 2006;8(4):409-414.

31. Yoshie, Y, Wang W, Hsieh YP, et al. Compositional difference of phenolic compounds between two seaweeds, Halimeda spp. J Tokyo Univ Fis. 2002;88:21-24.

32. Sampath-Wiley P, Neefus CD, Jahnke LS. Seasonal effects of sun exposure and emersion on intertidal seaweed physiology: Fluctuations in antioxidant contents, photosynthetic pigments and photosynthetic efficiency in the red alga Porphyra umbilicalis Kützing (Rhodophyta, Bangiales). J Exp Mar Biol Ecol. 2008;361:83-91.

33. Ballantine DL, Gerwick W H, Velez SM, et al. Antibiotic activity of lipid-soluble extracts from Caribbean marine algae. Hydrobiologia. 1987;151/152:463-469.

34. Gupta MP, Gomez N, Santana AI. Actividad antimicrobiana de algunas algas de la costa atlántica panameña. Rev Med Panama. 1991;16(1):64-68.

35. Ballesteros E, Martin D, Uriz MJ. Biological activity of extracts from some Mediterranean macrophytes. Botanica Marina. 1995;35:481-485.

36. Dzeha T, Jaspars M, Tabudravu J. Clionasterol, a triterpenoid from the Kenyan marine green macroalga Halimeda macroloba. Western Indian Ocean J Marine Sci. 2003;2(2):157-161.

37. Nor AS, Darah I, Shaida FS, et al. Antimicrobial activity of various extracts of a tropical Chlorophyta macroalgae Halimeda discoidea. $J$ Appl Sci. 2010;10(23):3007-3013.

38. Huang HL, Wu SL, Liao HF, et al. Induction of apoptosis by three marine algae through generation of reactive oxygen species in human leukemic cell lines. J Agric Food Chem. 2005;53(5):1776-1781.

39. Moo-Puc R, Robledo D, Freile-Pelegrin Y. Evaluation of selected tropical seaweeds for in vitroanti-trichomonal activity. $J$ Ethnopharmacol. 2008;120(1):92-97.

40. Boochum W, Peerapornpisal Y, Kanjanapothi D. Antimicrobial and antiinflammatory properties of various seaweeds from the Gulf of Thailand. Int J Agric Biol. 2011;13(1):100-104.

41. Harada H, Kamei Y. Dose-dependent selective cytotoxicity of extracts from marine green alga, Cladophoropsis vaucheriaeformis, against mouse leukemia L1210 cells. Biol Pharm Bull. 1998;21(4):186-389.

42. Zubia M, Robledo D, Freile-Pelegrin Y. Antioxidant activities in tropical marine Macroalgae from the Yucatan Peninsula, Mexico. Journal of Applied Phycology. 2007;19(5):449-458. 
43. Zaldivar $\mathrm{C}, \mathrm{Costa} \mathrm{A}, \mathrm{Batista} \mathrm{AE}$. Antioxidant activity and atheroprotective effect of an aqueous extract the marine seaweed Halimeda incrassata. Rev Cub Farm. 2009;43(supplement 1):88.

44. Costa-Mugica A, Batista-Gonzalez AE, Mondejar D, et al. Inhibition of LDL-oxidation and antioxidant properties related to polyphenols content of hydrophilic fractions from seaweed Halimeda incrassata(Ellis) Lamouroux. Braz J Pharm Sci. 2012;48(1):31-37.

45. Costa-Mugica A, Batista-González AE, Mondejar D. In vitro antiatherogenicity of extracts from Halimeda incrassata seaweed: antioxidant activity and smooth muscle cell migration studies. Ars Pharm. 2013;54(2):4-11.
46. Takeshi S, Yumiko Y-S, Joko S. Mineral components and antioxidant activities of tropical seaweeds. Journal of Ocean University of China. 2005;4(3):205-208.

47. Nakai M, Kageyama, Nakahara K, et al. Phlorotannins as radical scavengers from the extract of Sargassum ringgoldianum. Mar Biotechnol. 2006;8(4):409-414. 